\author{
Katarzyna Jankowska ${ }^{a)^{*}}$, Agnieszka Kowalczyka), Marta Iwańska ${ }^{a)}$ \\ a) Scientific and Research Centre for Fire Protection- National Research Institute / Centrum Naukowo-Badawcze Ochrony \\ Przeciwpożarowej im. Józefa Tuliszkowskiego - Państwowy Instytut Badawczy \\ "Corresponding author / Autor korespondencyjny: kjankowska@cnbop.pl
}

\author{
Changes in the Requirements for Placing Construction Products for Fire Protection \\ Marked with a Construction Mark on the Market or Making Them Available \\ on the National Market - Update
}

\title{
Zmiany w zakresie wymagań wprowadzania do obrotu lub udostępniania na rynku krajowym wyrobów budowlanych stużących ochronie przeciwpożarowej znakowanych znakiem budowlanym - aktualizacja
}

\begin{abstract}
Aim: The requirements for placing construction products for fire protection marked with a construction mark on the market or making them available on the national market result from the applicable legal acts. The article aims to present the current requirements and to analyze the changes introduced over the last two years. It contains a valid list of construction products for fire protection, for which it is necessary to carry out national assessment and verification of constancy of performance, as well as a summary of information related to the update of the definitions.

Introduction: In 2017, the Regulation of the Minister of Infrastructure and Construction on the method of declaring the performance of construction products and the method of marking them with a construction mark entered into force. It also concerned products used in fire protection [1]. The previous legal act that was in force in this area was the 2018 regulation [2]. In the article published in the fourth issue of "BITP. Safety and Fire Technique" from 2018 [8], the authors discussed the changes introduced then. More than 2 years have passed since the previous article was written, and the 2017 regulation has four amending acts, which - according to the authors - also deserve clarification. The changes to these regulations included updating the list of construction products for which national assessment and verification of constancy of performance is carried out, amendment of the definitions and extension of the transition periods.

Methodology: In order to present changes in the scope of the requirements for placing construction products for fire protection marked with a construction mark on the market or making them available on the national market, an analysis was carried out of the acts amending the regulation of the Minister of Infrastructure and Construction of 17 November 2016 on the method of declaring the performance of construction products and the method of marking their construction mark. On the basis of the analysis, the scope of changes was presented along with an indication of their impact on national assessment and verification of constancy of performance.

Conclusions: This article presents changes over the last 2 years in the requirements for placing construction products for fire protection marked with a construction mark on the market or making them available on the domestic market.

Keywords: construction product, marking with a construction mark, national assessment of constancy of performance
\end{abstract}

Type of article: review article

Received: 18.05.2021; Reviewed: 06.06.2021; Accepted: 28.06.2021;

Authors` ORCID IDs: K. Jankowska - 0000-0001-9678-2542; A. Kowalczyk - 0000-0002-5815-2037; M. Iwańska - 0000-0003-4815-7296

The authors contributed the equally to this article;

Please cite as: SFT Vol. 57 Issue 1, 2021, pp. 146-158, https://doi.org/10.12845/sft.57.1.2021.10;

This is an open access article under the CC BY-SA 4.0 license (https://creativecommons.org/licenses/by-sa/4.0/).

\section{ABSTRAKT}

Cel: Wymagania w zakresie wprowadzania do obrotu lub udostępniania na rynku krajowym wyrobów budowlanych służących ochronie przeciwpożarowej znakowanych znakiem budowlanym wynikają z obowiązujących aktów prawnych. Artykuł ma na celu przedstawienie aktualnych wymagań oraz analizę wprowadzonych zmian na przestrzeni ostatnich dwóch lat. Zawiera on obowiązującą listę wyrobów budowlanych służących ochronie przeciwpożarowej, dla których niezbędne jest przeprowadzenie krajowej oceny i weryfikacji stałości właściwości użytkowych, a także podsumowanie informacji związanych z aktualizacją definicji. 
Wprowadzenie: W 2017 roku weszło w życie rozporządzenie Ministra Infrastruktury i Budownictwa w sprawie sposobu deklarowania właściwości użytkowych wyrobów budowlanych oraz sposobu znakowania ich znakiem budowlanym dotyczące także wyrobów stosowanych w ochronie przeciwpożarowej [1]. Poprzednim aktem prawnym, który obowiązywał w tym zakresie było rozporządzenie z roku 2018 [2]. W tamtym czasie autorzy omówili wprowadzone zmiany w artykule opublikowanym w czwartym numerze „BITP. Bezpieczeństwo i Technika Pożarnicza” z 2018 roku [8]. Od momentu powstania poprzedniego artykułu minęły ponad 2 lata, a rozporządzenie z 2017 r. doczekało się czterech aktów zmieniających, które - zdaniem autorów - także zasługują na wyjaśnienie. Zmiany w tych przepisach obejmowały aktualizację wykazu wyrobów budowlanych, dla których dokonuje się krajowej oceny i weryfikacji stałości właściwości użytkowych, nowelizację definicji oraz wydłużenie okresów przejściowych.

Metodologia: W celu przedstawienia zmian w zakresie wymagań wprowadzania do obrotu lub udostępniania na rynku krajowym wyrobów budowlanych służących ochronie przeciwpożarowej znakowanych znakiem budowlanym dokonano analizy aktów zmieniających rozporządzenie Ministra Infrastruktury i Budownictwa z dnia 17 listopada 2016 r. w sprawie sposobu deklarowania właściwości użytkowych wyrobów budowlanych oraz sposobu znakowania ich znakiem budowlanym. Na podstawie wykonanej analizy zaprezentowano zakres zmian wraz ze wskazaniem ich wpływu na przeprowadzanie krajowej oceny i weryfikacji stałości właściwości użytkowych.

Wnioski: Niniejszy artykuł przedstawia zmiany w wymaganiach dotyczących wprowadzania do obrotu lub udostępniania na rynku krajowym wyrobów budowlanych służących ochronie przeciwpożarowej znakowanych znakiem budowlanym na przestrzeni ostatnich 2 lat.

Słowa kluczowe: wyrób budowlany, znakowanie znakiem budowlanym, krajowa ocena stałości właściwości użytkowych

Typ artykułu: artykuł przeglądowy

Przyjęty: 18.05.2021; Zrecenzowany: 06.06.2021; Zaakceptowany: 28.06.2021;

Identyfikatory ORCID autorów: K. Jankowska - 0000-0001-9678-2542; A. Kowalczyk - 0000-0002-5815-2037; M. Iwańska - 0000-0003-4815-7296. Autorzy wnieśli równy wkład merytoryczny w powstanie artykułu;

Proszę cytować: SFT Vol. 57 Issue 1, 2021, pp. 146-158, https://doi.org/10.12845/sft.57.1.2021.10;

Artykuł udostępniany na licencji CC BY-SA 4.0 (https://creativecommons.org/licenses/by-sa/4.0/)

\section{Introduction}

Legal provisions are constantly changing, which results in the need to apply the latest legislation, including requirements and definitions, maintaining a transitional period for their entry into force. Construction products used on their own, in fire systems or installations, must meet the requirements related to the confirmation of their constancy of performance. The above is regulated by the applicable legal acts which have changed four times over the last five years.

The article presents an update of the content discussed in the work entitled Changes in the requirements for placing construction products for fire protection marked with a construction mark on the market or making them available on the national market published in "BITP. Safety and Fire Technique" Vol. 52 Issue 4, 2018 [8]. It aims to present the scope of changes in the acts amending the Regulation of the Minister of Infrastructure and Construction of 17 November 2016 [1] on the method of declaring the performance of construction products and the method of marking them with a construction mark in the area of construction products for fire protection marked with a construction mark.

\section{The scope of changes in the acts amending the Regulation of the Minister of Infrastructure and Construction of 17 November 2016}

The Regulation of the Minister of Investment and Development of 13 June 2018 [2] amending the regulation on the method of declaring the performance of construction products and the

\section{Wprowadzenie}

Przepisy prawne zmieniają się nieustająco, co skutkuje koniecznością stosowania najnowszego prawodawstwa w tym wymagań i definicji z zachowaniem okresu przejściowego ich wejścia w życie. Wyroby budowlane stosowane samodzielnie, w systemach lub instalacjach pożarowych muszą spełniać wymagania związane z potwierdzeniem ich stałości właściwości użytkowych. Powyższe regulowane jest mającymi zastosowanie aktami prawnymi, które na przestrzeni ostatnich pięciu lat zmieniały się czterokrotnie.

Artykuł przedstawia aktualizację treści omówionych w pracy Zmiany w zakresie wymagań wprowadzania do obrotu lub udostępniania na rynku krajowym wyrobów budowlanych służących ochronie przeciwpożarowej znakowanych znakiem budowlanym opublikowanej w „BITP. Bezpieczeństwo i Technika Pożarnicza" Vol. 52 Issue 4, 2018 [8]. Ma on na celu przybliżenie zakresu zmian w aktach zmieniających rozporządzenie Ministra Infrastruktury i Budownictwa z dnia 17 listopada 2016 r. [1] w sprawie sposobu deklarowania właściwości użytkowych wyrobów budowlanych oraz sposobu znakowania ich znakiem budowlanym w zakresie wyrobów budowlanych służących ochronie przeciwpożarowej znakowanych znakiem budowlanym.

\section{Zakres zmian w aktach zmieniających rozporządzenie Ministra Infrastruktury i Budownictwa z dnia 17 listopada 2016 r.}

Rozporządzenie Ministra Inwestycji i Rozwoju z dnia 13 czerwca 2018 r. [2] zmieniające rozporządzenie w sprawie sposobu deklarowania właściwości użytkowych wyrobów 
method of marking them with a construction mark introduced a change in the form of extending the transitional period related to marking and issuing national declarations for construction products, which was not included in the previous regulation. Annex 1 to the Regulation [1] was also updated, to include groups of construction products covered by the obligation to draw up a national declaration of performance and the national systems of assessment and verification of constancy of performance required for these groups.

The Regulations of the Minister of Investment and Development of 19 June 2019 [9] additionally extended the transitional period for marking and issuing national declarations for construction products not included in the previous legal act.

The regulation of the Minister of Finance, Investment and Development of 21 October 2019 [10] introduced the following changes:

1. In paragraph 1, the definition of the Polish Standard was changed, the information indicating that the Polish Standard is not a standard having the status of "withdrawn" has been removed. Therefore, it was possible to declare performance and mark construction products with a construction mark in accordance with the Polish Standards, which have been withdrawn. The objection to the above is indicated in paragraph 2 , which specifies the documents on the basis of which assessment and verification of constancy of performance are performed. These documents are:

- Polish Standard that does not have the status of a withdrawn standard,

- Polish Standard with the status of a withdrawn standard (but not longer than one year from the date of its withdrawal or until the date indicated in the foreword of the superseding standard, as the date of withdrawal of national standards inconsistent with a given standard, if this period is longer than one year or national technical assessments).

2. Paragraph 3 changes the scope of assessment and verification carried out by a certification body in system $1+, 1,2+$ from "assessment of performance of a construction product on the basis of testing samples taken by the certification body, calculations, tabular values or descriptive documentation of this product" to "assessment of performance of a construction product on the basis of sample testing, including sampling, calculations, tabular values or descriptive documentation of this product". Therefore, this amendment removed the need for a sample to be taken by the certification body. The current provision indicates that the certification body assesses and verifies the sampling, and is not directly responsible for it.

3. Paragraph 4 updated the legal act indicated in $\S 5$, which referred to the definition of a microentrepreneur.

The regulation of the Minister of Development, Labour and Technology of 4 December 2020 [4] updated the provisions in the table in Annex 1 to the regulation, which covers the groups budowlanych oraz sposobu znakowania ich znakiem budowlanym wprowadziło zmianę w postaci wydłużenia okresu przejściowego związanego ze znakowaniem i wydawaniem krajowych deklaracji dla wyrobów budowlanych nieujętych w poprzednim rozporządzeniu.

Zaktualizowany został również załącznik 1 do rozporządzenia [1] obejmujący grupy wyrobów budowlanych objętych obowiązkiem sporządzania krajowej deklaracji właściwości użytkowych oraz wymaganych dla tych grup krajowych systemów oceny i weryfikacji stałości właściwości użytkowych.

Rozporządzenie Ministra Inwestycji i Rozwoju z dnia 19 czerwca 2019 r. [9] dodatkowo wydłużyło okres przejściowy dotyczący znakowania i wydawania krajowych deklaracji dla nieujętych w poprzednim rozporządzeniu wyrobów budowlanych.

Rozporządzenie Ministra Finansów, Inwestycji i Rozwoju z dnia 21 października 2019 r. [10] wprowadziło poniższe zmiany:

1. W ustępie 1 zmieniono definicję Polskiej Normy, usunięto informację, która wskazywała, że Polską Normą nie jest norma mająca status "wycofanej”. W związku z tym umożliwiono deklarowanie właściwości użytkowych oraz znakowanie znakiem budowlanym wyrobów budowlanych zgodnie z Polskimi Normami, które zostały wycofane. Zastrzeżenie do powyższego wskazano w ustępie 2, doprecyzowującym dokumenty, w oparciu o które wykonuje się ocenę i weryfikację stałości właściwości użytkowych. Tymi dokumentami są:

- Polska Norma niemająca statusu normy wycofanej,

- Polska Norma mająca status normy wycofanej (nie dłużej jednak niż przez rok od daty jej wycofania albo do daty wskazanej w przedmowie normy zastępującej, jako daty wycofania krajowych norm sprzecznych z daną normą, jeśli okres ten jest dłuższy niż rok albo krajowych ocen technicznych).

2. Ustęp 3 zmienia zakres oceny i weryfikacji przeprowadzanej przez jednostkę certyfikującą w systemie $1+, 1$, $2+z$ "oceny właściwości użytkowych wyrobu budowlanego na podstawie badań próbek pobranych przez jednostkę certyfikującą, obliczeń, tabelarycznych wartości lub opisowej dokumentacji tego wyrobu" na "ocenę właściwości użytkowych wyrobu budowlanego na podstawie badań próbek, w tym ich pobierania, obliczeń, tabelarycznych wartości lub opisowej dokumentacji tego wyrobu". Niniejsza zmiana usunęła tym samym konieczność pobierania próbki przez jednostkę certyfikującą. Obecny zapis wskazuje, iż jednostka certyfikująca dokonuje oceny i weryfikacji poboru próbki, a nie jest za nią bezpośrednio odpowiedzialna.

3. Ustęp 4 zaktualizował akt prawny wskazany $w$ treści $\S 5$, powołujący definicję mikroprzedsiębiorcy.

Rozporządzenie Ministra Rozwoju, Pracy i Technologii z dnia 4 grudnia 2020 r. [4] wprowadziło aktualizację zapisów znajdujących się $w$ tabeli w załączniku 1 do rozporządzenia, 
of construction products covered by the obligation to prepare a national declaration of performance and the national assessment systems required for these groups and verification of constancy of performance. The changes are indicated in the next chapter in the form of a table.

\section{Construction products used in fire protection}

This article applies to construction products for which no harmonized standard has been developed or where at least one of the essential characteristics of the product is outside the scope of a harmonized standard or a European Technical Assessment. The list of construction products is presented in the Regulation of the Minister of Infrastructure and Construction of November 17, 2016 on the method of declaring the performance of construction products and the method of marking them with a construction mark (Polish Journal of Laws: Dz. U. z 2016 r. poz. 1966; amended by: Dz. U. z 2018 r. poz. 1233, z 2019 r. poz. 1176 i poz. 2164 and z 2020 r. poz. 2297) and was updated by two amending acts.

According to the annex to the Regulation of the Minister of Infrastructure and Construction of 17 November 2016 on the method of declaring the performance of construction products and marking them with a construction mark (Polish Journal of Laws: Dz. U. z 2016 r. poz. 1966), all the products listed below are covered by one national system of assessment and verification of constancy of performance. Information on the tasks of the manufacturer and the accredited body in relation to the applied system of assessment and verification of constancy of performance is presented in an article published in "Safety \& Fire Technique" in 2018 [8].

The compilation below is presented in Table 1. It covers construction products used in fire protection, which are subject to the obligation to declare performance and mark them with a construction mark with the division into the above-mentioned regulations, as well as products that were previously subject to the obligation to declare conformity and mark them with a construction mark.

The last amendment detailed in the table below involves the removal of two groups of construction products "Explosion protection systems - kits" and "Explosion protection systems - components", removal of individual products and further specification of product names. który obejmuje grupy wyrobów budowlanych objętych obowiązkiem sporządzania krajowej deklaracji właściwości użytkowych oraz wymaganych dla tych grup krajowych systemów oceny i weryfikacji stałości właściwości użytkowych. Zmiany wskazano w kolejnym rozdziale w postaci tabeli.

\section{Wyroby budowlane stosowane w ochronie przeciwpożarowej}

Niniejszy artykuł dotyczy wyrobów budowlanych, dla których nie opracowano normy zharmonizowanej lub gdy chociaż jedna z zasadniczych charakterystyk wyrobu wykracza poza zakres normy zharmonizowanej lub europejskiej oceny technicznej. Wykaz wyrobów budowlanych został przedstawiony w rozporządzeniu Ministra Infrastruktury i Budownictwa z dnia 17 listopada 2016 r. w sprawie sposobu deklarowania właściwości użytkowych wyrobów budowlanych oraz sposobu znakowania ich znakiem budowlanym (Dz. U. z 2016 r. poz. 1966; zm.: Dz. U. z 2018 r. poz. 1233, z 2019 r. poz. 1176 i poz. 2164 oraz z 2020 r. poz. 2297) i był aktualizowany w dwóch aktach zmieniających.

Zgodnie z załącznikiem do rozporządzenia Ministra Infrastruktury i Budownictwa z dnia 17 listopada 2016 r. w sprawie sposobu deklarowania właściwości użytkowych wyrobów budowlanych oraz sposobu znakowania ich znakiem budowlanym (Dz. U. z 2016 r. poz. 1966) wszystkie niżej wymienione wyroby objęte są jednym krajowym systemem oceny i weryfikacji stałości właściwości użytkowych. Informacje dotyczące zadań producenta i akredytowanej jednostki w odniesieniu do zastosowanego systemu oceny i weryfikacji stałości właściwości użytkowych zostały przestawione $w$ artykule opublikowanym w BiTP w 2018 r. [8].

Poniższe zestawienie zostało przestawione $w$ tabeli 1. Obejmuje ono wyroby budowlane stosowane $w$ ochronie przeciwpożarowej, które podlegają obowiązkowi deklarowania właściwości użytkowych oraz znakowania ich znakiem budowlanym z podziałem na ww. rozporządzenia, a także wyroby, które wcześniej podlegały obowiązkowi deklarowania zgodności i znakowania ich znakiem budowlanym.

Ostatnia zmiana wyszczególniona w poniższej tabeli obejmuje usunięcie dwóch grup wyrobów budowlanych "Systemy zabezpieczenia przed wybuchem - zestawy" oraz "Systemy zabezpieczenia przed wybuchem - elementy składowe", usunięcie pojedynczych wyrobów oraz doszczegółowienie nazw wyrobów. 


\begin{abstract}
Annex 1 to the Regulation of the Minister of Infrastructure of 11 August 2004 on the methods of declaring the conformity of construction products and the method of marking them with a construction mark (Polish Journal of Laws: Dz. U. $2004 \mathrm{nr} 198$ poz. 2041 as amended) /

Załącznik nr 1 do rozporządzenia Ministra Infrastruktury z dnia

11 sierpnia 2004 r. w sprawie sposobów deklarowania zgodności wyrobów

budowlanych oraz sposobu znakowania ich znakiem budowlanym (Dz.U. 2004 nr 198 poz. 2041 z późn.zm.)
\end{abstract}

Annex 1 to the Regulation of the Minister of Infrastructure and Construction of 17 November 2016 on the method of declaring the performance of construction products and the method of marking them with a construction mark (Polish Journal of Laws: Dz. U. 2016 poz. 1966) /

Załącznik nr 1 do rozporządzenia Ministra Infrastruktury i Budownictwa z dnia 17 listopada $2016 \mathrm{r}$. w sprawie sposobu deklarowania właściwości użytkowych wyrobów budowlanych oraz sposobu znakowania ich znakiem budowlanym (Dz. U. 2016 poz. 1966)
96/577/EC Commission Decision of 24 June 1996 on the procedure for attesting the conformity of construction products pursuant to Art. 120 sec. 2 of Directive 89/106/EEC concerning fixed firefighting appliances / 96/577/WE Decyzja Komisji z dnia 24 czerwca 1996 r. w sprawie procedury atestowania zgodności wyrobów budowlanych zgodnie $z$ art. 120 ust. 2 dyrektywy 89/106/EWG dotyczącym stałych urządzeń gaśniczych
Group 10: Fixed firefighting equipment (products for fire detection and alarming, products for heat and smoke control and explosion suppression, evacuation systems) /

Grupa 10: Stałe urządzenia przeciwpożarowe (wyroby do wykrywania

i sygnalizacji pożaru, wyroby do kontroli rozprzestrzeniania ciepła i dymu oraz tłumienia wybuchu, systemy ewakuacyjne)
Fire alarm systems - kits:

signaling and alarm kits, fire alarm kits, alarm systems, warning and evacuation systems /

Systemy sygnalizacji pożarowej - zestawy:

zestawy sygnalizacyjno-alarmowe, zestawy sygnalizacji pożarowej, systemy alarmowe, systemy ostrzegania i ewakuacji
Fire alarm systems - kits:

signaling and alarm kits, fire alarm kits, alarm systems,

fire alarm transmission systems /

Systemy sygnalizacji pożarowej - zestawy:

zestawy sygnalizacyjno-alarmowe, zestawy sygnalizacji pożarowej, systemy alarmowe, systemy transmisji alarmów pożarowych
Fire alarm systems - components:

fire detectors, control and signaling devices, alarm transmission devices, short circuit insulators, alarm devices, power sources, input/output devices, manual call points, voice alarm systems /

Systemy sygnalizacji pożarowej - elementy składowe: czujki pożarowe, urządzenia sterujące i sygnalizujące, urządzenia transmisji alarmów, izolatory zwarć, urządzenia alarmowe, urządzenia wejścia/ wyjścia, ręczne ostrzegacze pożarowe, dźwiękowe systemy ostrzegawcze
Fire alarm systems - components:

fire detectors, control and signaling devices, alarm transmission devices, short circuit insulators, alarm devices, power sources, input/output devices, manual call points, control panels for fire brigades, devices for remote signaling and service, mounting sockets for linear elements, alarm displays, standalone fire detectors, standalone carbon monoxide detectors, power sources / Systemy sygnalizacji pożarowej - elementy składowe:

czujki pożarowe, urządzenia sterujące i sygnalizujące, urządzenia transmisji alarmów, izolatory zwarć, urządzenia alarmowe, źródła zasilania, urządzenia wejścia/wyjścia, ręczne ostrzegacze pożarowe, panele obsługi dla straży pożarnej, urządzenia zdalnej sygnalizacji i obsługi, gniazda montażowe elementów liniowych, wskaźniki zadziałania, autonomiczne czujki pożarowe, autonomiczne czujki tlenku węgla, źródła zasilania
Fire suppression and extinguishing systems - kits: dry and wet hydrant systems, sprinkler, water spray and water mist systems - kits, foam extinguishing kits, dry powder extinguishing kits, gas extinguishing kits (including $\mathrm{CO}_{2}$ extinguishing systems) / Systemy tłumienia i gaszenia pożaru - zestawy: systemy instalacji hydrantowych suchych i nawodnionych, zestawy instalacji tryskaczowych, zraszaczowych i mgły wodnej, zestawy gaśnicze pianowe, zestawy gaśnicze proszkowe, zestawy gaśnicze gazowe ( $w$ tym systemy gaśnicze z $\mathrm{CO}_{2}$ )
Fire suppression and extinguishing systems - kits:

hose reels, dry and wet hydrant systems, sprinkler, water spray and water mist systems - kits, foam extinguishing kits, dry powder extinguishing kits, gas extinguishing kits (including $\mathrm{CO}_{2}$ extinguishing systems), aerosol extinguishing kits, spark extinguishing kits, kits for reducing the concentration of oxygen / Systemy tłumienia i gaszenia pożaru - zestawy:

hydranty wewnętrzne, instalacje hydrantowe suche i nawodnione, zestawy instalacji tryskaczowych, zraszaczowych i mgły wodnej, zestawy gaśnicze pianowe, zestawy gaśnicze proszkowe, zestawy gaśnicze gazowe (w tym systemy gaśnicze z $\mathrm{CO}_{2}$ ), zestawy gaśnicze aerozolowe, zestawy do gaszenia iskier, zestawy do redukcji stężenia tlenu 
Annex to the Regulation of the Minister of Investment and Development of 13 June 2018 amending the Regulation on the method of declaring the performance of construction products and the method of marking them with a construction mark (Polish Journal of Laws: Dz. U. 2018 poz. 1233) / Załącznik do rozporządzenia Ministra Inwestycji i Rozwoju z dnia 13 czerwca 2018 r. zmieniającego rozporządzenie w sprawie sposobu deklarowania właściwości użytkowych wyrobów budowlanych oraz sposobu znakowania ich znakiem budowlanym (Dz.U. 2018 poz. 1233)
Regulation of the Minister of Development, Labor and Technology of 4 December 2020 amending the Regulation on the method of declaring the performance of construction products and the method of marking them with a construction mark (Polish Journal of Laws: Dz. U. 2020 poz. 2297) /

Rozporządzenie Ministra Rozwoju, Pracy i Technologii z dnia

4 grudnia 2020 r. zmieniające rozporządzenie $w$ sprawie sposobu deklarowania właściwości użytkowych wyrobów budowlanych oraz sposobu znakowania ich znakiem budowlanym
Group 10: Fixed firefighting equipment (products for fire detection and alarming, products for heat and smoke control and explosion suppression, evacuation systems) /

Grupa 10: Stałe urządzenia przeciwpożarowe (wyroby do wykrywania

i sygnalizacji pożaru, wyroby do kontroli rozprzestrzeniania ciepła i dymu oraz tłumienia wybuchu, systemy ewakuacyjne)
Group 10: Fixed firefighting equipment (products for fire detection and alarming, products for heat and smoke control and explosion suppression, evacuation systems) /

Grupa 10: Stałe urządzenia przeciwpożarowe (wyroby do wykrywania

i sygnalizacji pożaru, wyroby do kontroli rozprzestrzeniania ciepła i dymu oraz tłumienia wybuchu, systemy ewakuacyjne)
Fire alarm systems - kits:

signaling and alarm kits, fire alarm kits, alarm systems,

fire alarm transmission systems /

Systemy sygnalizacji pożarowej - zestawy:

zestawy sygnalizacyjno-alarmowe, zestawy sygnalizacji pożarowej,

systemy alarmowe, systemy transmisji alarmów pożarowych
Fire alarm systems - kits:

signaling and alarm kits, fire alarm kits, alarm systems,

fire alarm transmission systems /

Systemy sygnalizacji pożarowej - zestawy:

zestawy sygnalizacyjno-alarmowe, zestawy sygnalizacji pożarowej systemy alarmowe, systemy transmisji alarmów pożarowych
Fire alarm systems - components:

fire detectors, control and signaling devices, alarm transmission devices, short circuit insulators, alarm devices, power sources, input/output devices, manual call points, control panels for fire brigades, devices for remote signaling and service, mounting sockets for lintors, power sources /

Systemy sygnalizacji pożarowej - elementy składowe:

czujki pożarowe, urządzenia sterujące i sygnalizujące, urządzenia transmisji alarmów, izolatory zwarć, urządzenia alarmowe, źródła zasilania, urządzenia wejścia/wyjścia, ręczne ostrzegacze pożarowe, panele obsługi dla straży pożarnej, urządzenia zdalnej sygnalizacji i obsługi, gniazda montażowe elementów liniowych, wskaźniki zadziałania, autonomiczne czujki pożarowe, autonomiczne czujki tlenku węgla, źródła zasilania
Fire alarm systems - components:

fire detectors, control and signaling devices, alarm transmission devices, short circuit insulators, alarm devices, power sources, input/output devices, manual call points, control panels for fire brigades, devices for remote signaling and service, external alarm displays, standalone fire detectors, standalone carbon monoxide detectors /

Systemy sygnalizacji pożarowej - elementy składowe:

czujki pożarowe, urządzenia sterujące i sygnalizujące, urządzenia transmisji alarmów, izolatory zwarć, urządzenia alarmowe, źródła zasilania, urządzenia wejścia/ wyjścia, ręczne ostrzegacze pożarowe, panele obsługi dla straży pożarnej, urządzenia zdalnej sygnalizacji i obsługi, wyniesione wskaźniki zadziałania, autonomiczne czujki pożarowe, autonomiczne czujki tlenku węgla
Fire suppression and extinguishing systems - kits:

hose reels, dry and wet hydrant systems, sprinkler, water spray and water miear elements, alarm displays, standalone fire detectors, standalone carbon monoxide detection systems - kits, foam extinguishing kits, dry powder extinguishing kits, gas extinguishing kits (including $\mathrm{CO}_{2}$ extinguishing systems), aerosol extinguishing kits, spark extinguishing kits, kits for reducing the concentration of oxygen / Systemy tłumienia i gaszenia pożaru - zestawy:

hydranty wewnętrzne, instalacje hydrantowe suche i nawodnione, zestawy instalacji tryskaczowych, zraszaczowych i mgły wodnej, zestawy gaśnicze pianowe, zestawy gaśnicze proszkowe, zestawy gaśnicze gazowe ( $w$ tym systemy gaśnicze $z \mathrm{CO}_{2}$ ), zestawy gaśnicze aerozolowe, zestawy do gaszenia iskier, zestawy do redukcji stężenia tlenu
Fire suppression and extinguishing systems - kits:

hose reels, dry and wet hydrant systems, sprinkler, water spray and water mist systems - kits,foam extinguishing kits, dry powder extinguishing kits, gas extinguishing kits (including $\mathrm{CO}_{2}$ extinguishing systems), aerosol extinguishing kits, spark extinguishing kits, kits for reducing the concentration of oxygen / Systemy tłumienia i gaszenia pożaru - zestawy:

hydranty wewnętrzne, instalacje hydrantowe suche i nawodnione, zestawy instalacji tryskaczowych, zraszaczowych i mgły wodnej, zestawy gaśnicze pianowe, zestawy gaśnicze proszkowe, zestawy gaśnicze gazowe (w tym systemy gaśnicze $\mathrm{z} \mathrm{CO}_{2}$ ), zestawy gaśnicze aerozolowe, zestawy do gaszenia iskier, zestawy do redukcji stężenia tlenu 
Annex 1 to the Regulation of the Minister of Infrastructure of 11 August 2004 on the methods of declaring the conformity of construction products and the method of marking them with a construction mark (Polish Journal of Laws: Dz. U. $2004 \mathrm{nr} 198$ poz. 2041 as amended) /

Załącznik nr 1 do rozporządzenia Ministra Infrastruktury $z$ dnia 11 sierpnia 2004 r. w sprawie sposobów deklarowania zgodności wyrobów budowlanych oraz sposobu znakowania ich znakiem budowlanym (Dz.U. 2004 nr 198 poz. 2041 z późn.zm.)
Annex 1 to the Regulation of the Minister of Infrastructure and Construction of 17 November $\mathbf{2 0 1 6}$ on the method of declaring the performance of construction products and the method of marking them with a construction mark (Polish Journal of Laws: Dz. U. 2016 poz. 1966) /

Załącznik nr 1 do rozporządzenia Ministra Infrastruktury i Budownictwa z dnia 17 listopada $2016 \mathrm{r}$. w sprawie sposobu deklarowania właściwości użytkowych wyrobów budowlanych oraz sposobu znakowania ich znakiem budowlanym (Dz. U. 2016 poz. 1966)
Fire suppression and extinguishing systems - components: hose reels, water flow sensors/switches, pressure sensors/switches, fire valves, couplings, fire pumps and fire pump assemblies, nozzles, sprinklers/outlet fittings /

Systemy tłumienia i gaszenia pożaru - elementy składowe: hydranty wewnętrzne, czujniki/przełączniki przepływu wody, czujniki/ przełączniki ciśnienia, zawory pożarowe, nasady, pompy przeciwpożarowe i zespoły pomp przeciwpożarowych, dysze, tryskacze/łączniki wylotowe
Fire suppression and extinguishing systems - components: external hydrants, water flow sensors/switches, pressure sensors/switches, hydrant fire valves, connections for fire brigades, fire pumps and fire pump assemblies, nozzles/sprinklers/water sprays/outlet fittings, water control and alarm valve assemblies, air control and alarm valve assemblies, excitation valve assemblies, multiple controls, pressure vessel valve assemblies and their actuators, selector valves and their actuators, non-electric locking devices, flexible couplings, pressure gauges and pressure switches, mechanical weighing devices, check and non-return valves, control and signaling devices, power sources, foam concentrate dispensers, foam nozzles, pumps for fire-fighting water systems, flexible hose couplings, groove couplings for pipes, groove fittings for pipes, plastic piping systems, inlet valves and gate valves, pipe hangers and sets of hangers, pressure limiting and regulating valves, extinguishing agent tanks, inlet manifolds and triple head distributors, filters, control panels for fire brigades /

Systemy tłumienia i gaszenia pożaru - elementy składowe: hydranty zewnętrzne, czujniki/przełączniki przepływu wody, czujniki/ przełączniki ciśnienia, zawory pożarowe hydrantowe, przyłącza dla straży pożarnej, pompy pożarowe i zespoły pomp pożarowych, dysze/tryskacze/zraszacze/ elementy wylotowe, zespoły zaworów kontrolno-alarmowych wodnych, zespoły zaworów kontrolno-alarmowych powietrznych, zespoły zaworów wzbudzających, pobudzacze, zespoły zaworów zbiorników ciśnieniowych i ich urządzenia wyzwalające, zawory kierunkowe i ich urządzenia wyzwalające, nieelektryczne urządzenia blokujące, łączniki elastyczne, ciśnieniomierze i łączniki ciśnienia, mechaniczne urządzenia wagowe, zawory zwrotne i jednokierunkowe, urządzenia sterujące i sygnalizujące, źródła zasilania, dozowniki środka pianotwórczego, prądownice pianowe, pompy instalacji wodociagowych przeciwpożarowych, łączniki elastyczne wężowe, złącza rowkowe do rur, kształtki rowkowe do rur, systemy rurowe z tworzyw sztucznych, zawory i zasuwy wlotowe, uchwyty i zestawy mocowania przewodów rurowych, zawory ograniczania i regulacji ciśnienia, zbiorniki środków gaśniczych, kolektory wlotowe i rozdzielcze, filtry, panele obsługi dla straży pożarnej
Explosion protection systems - kits /

Systemy zabezpieczenia przed wybuchem - zestawy
Explosion protection systems - kits /

Systemy zabezpieczenia przed wybuchem - zestawy
Explosion protection systems - components:

detectors, suppression devices, explosion detectors, explosion-proof products /

Systemy zabezpieczenia przed wybuchem - elementy składowe: czujki, tłumiki, czujniki wybuchu, wyroby przeciwwybuchowe
Explosion protection systems - components: detectors, suppression devices, explosion detectors, relief products, control and signaling devices, power sources, control panels for fire brigades / Systemy zabezpieczenia przed wybuchem - elementy składowe: czujki, urządzenia tłumiące, czujniki wybuchu, wyroby odciążające, urządzenia sterujące i sygnalizujące, źródła zasilania, panele obsługi dla straży pożarnej
Smoke and heat control systems - kits: smoke and heat extraction kits, pressure differential kits / Instalacje kontroli rozprzestrzeniania dymu i ciepła - zestawy: zestawy do odprowadzania dymu i ciepła, zestawy do różnicowania ciśnienia,
Smoke and heat control systems - kits:

smoke and heat extraction kits, pressure differential kits, fire cut-off control kits / Systemy kontroli rozprzestrzeniania dymu i ciepła - zestawy: zestawy do odprowadzania dymu i ciepła, zestawy do różnicowania ciśnienia, zestawy do sterowania odcięciami przeciwpożarowymi 
Annex to the Regulation of the Minister of Investment and Development of 13 June 2018 amending the Regulation on the method of declaring the performance of construction products and the method of marking them with a construction mark (Polish Journal of Laws: Dz. U. 2018 poz. 1233) / Załącznik do rozporządzenia Ministra Inwestycji i Rozwoju z dnia 13 czerwca 2018 r. zmieniającego rozporządzenie w sprawie sposobu deklarowania właściwości użytkowych wyrobów budowlanych oraz sposobu znakowania ich znakiem budowlanym (Dz.U. 2018 poz. 1233)
Regulation of the Minister of Development, Labor and Technology of 4 December 2020 amending the Regulation on the method of declaring the performance of construction products and the method of marking them with a construction mark (Polish Journal of Laws: Dz. U. 2020 poz. 2297) /

Rozporządzenie Ministra Rozwoju, Pracy i Technologii z dnia 4 grudnia 2020 r. zmieniające rozporządzenie w sprawie sposobu deklarowania właściwości użytkowych wyrobów budowlanych oraz sposobu znakowania ich znakiem budowlanym
Fire suppression and extinguishing systems - components: external hydrants, water flow sensors/switches, pressure sensors/switches, hydrant fire valves, connections for fire brigades, fire pumps and fire pump assemblies, nozzles/sprinklers/water sprays/outlet fittings, water control and alarm valve systems, air control and alarm valve assemblies, excitation valve assemblies, multiple controls, pressure vessel valve assemblies and their actuators, selector valves and their actuators, non-electric locking devices, flexible couplings, pressure gauges and pressure switches, mechanical weighing devices, check and non-return valves, control and signaling devices, power sources, foam concentrate dispensers, foam nozzles, pumps for fire-fighting water systems, fasteners, fittings, contro and shut-off fittings, pipe systems, pipe hangers and sets of hangers, extinguishing agent tanks, control panels for fire brigades /

Systemy tłumienia i gaszenia pożaru - elementy składowe: hydranty zewnętrzne, czujniki/przełączniki przepływu wody, czujniki/ przełączniki ciśnienia, zawory pożarowe hydrantowe, przyłącza dla straży pożarnej, pompy pożarowe i zespoły pomp pożarowych, dysze/tryskacze/ zraszacze/elementy wylotowe, zespoły zaworów kontrolno-alarmowych wodnych, zespoły zaworów kontrolno-alarmowych powietrznych, zespoły zaworów wzbudzających, pobudzacze, zespoły zaworów zbiorników ciśnieniowych i ich urządzenia wyzwalające, zawory kierunkowe i ich urządzenia wyzwalające, nieelektryczne urządzenia blokujące, łączniki elastyczne, ciśnieniomierze i łączniki ciśnienia, mechaniczne urządzenia wagowe, zawory zwrotne i jednokierunkowe, urządzenia sterujące i sygnalizujące, źródła zasilania, dozowniki środka pianotwórczego, prądownice pianowe, pompy do instalacji wodociągowych przeciwpożarowych, elementy złączne, kształtki, armatura regulacyjna i odcinająca, systemy rurowe, uchwyty i zestawy mocowania przewodów rurowych, zbiorniki środków gaśniczych, panele obsługi dla straży pożarnej
Fire suppression and extinguishing systems - components: external hydrants, water flow sensors/switches, pressure sensors/switches, hydrant fire valves, connections for fire brigades, fire pumps and fire pump assemblies, nozzles/sprinklers/water sprays/outlet fittings, water control and alarm valve systems, air control and alarm valve assemblies, excitation valve assemblies, multiple controls, pressure vessel valve assemblies and their actuators, selector valves and their actuators, non-electric locking devices, flexible couplings, pressure gauges and pressure switches, mechanical weighing devices, check and non-return valves, control and signaling devices, power sources,

foam concentrate dispensers, foam nozzles, pumps and pump assemblies for fire-fighting water systems, fasteners, fittings, control and shut-off fittings, plastic piping systems and metal clamped piping systems, extinguishing agent tanks, control panels for fire brigades /

Systemy tłumienia i gaszenia pożaru - elementy składowe: hydranty zewnętrzne, czujniki/ przełączniki przepływu wody, czujniki/przełączniki ciśnienia, zawory pożarowe hydrantowe, przyłącza dla straży pożarnej, pompy pożarowe i zespoły pomp pożarowych, dysze/tryskacze/zraszacze/ elementy wylotowe, zespoły zaworów kontrolno-alarmowych wodnych, zespoły zaworów kontrolno-alarmowych powietrznych, zespoły zaworów wzbudzających, pobudzacze, zespoły zaworów zbiorników ciśnieniowych i ich urządzenia wyzwalające, zawory kierunkowe i ich urządzenia wyzwalające, nieelektryczne urządzenia blokujące, łączniki elastyczne, ciśnieniomierze i łączniki ciśnienia, mechaniczne urządzenia wagowe, zawory zwrotne i jednokierunkowe, urządzenia sterujące i sygnalizujące, źródła zasilania, dozowniki środka pianotwórczego, prądownice pianowe, pompy i zespoły pomp do instalacji wodociągowych przeciwpożarowych, elementy złączne, kształtki, armatura regulacyjna i odcinająca, systemy rurowe z tworzyw sztucznych oraz systemy rurowe metalowe zaciskane, zbiorniki środków gaśniczych, panele obsługi dla straży pożarnej

Explosion protection systems - components: detectors, suppression devices, explosion detectors, relief products, control and signaling devices, power sources, control panels for fire brigades / Systemy zabezpieczenia przed wybuchem - elementy składowe: czujki, urządzenia tłumiące, czujniki wybuchu, wyroby odciążające, urzą-

Smoke and heat control systems - kits: smoke and heat extraction kits, pressure differential kits, fire cut-off control kits /

Systemy kontroli rozprzestrzeniania dymu i ciepła - zestawy: zestawy do odprowadzania dymu i ciepła, zestawy do różnicowania ciśnienia, zestawy do sterowania odcięciami przeciwpożarowymi
Smoke and heat control systems - kits:

smoke and heat extraction kits, pressure differential kits, fire cut-off control kits / Systemy kontroli rozprzestrzeniania dymu i ciepła - zestawy: zestawy do odprowadzania dymu i ciepła, zestawy do różnicowania ciśnienia, zestawy do sterowania odcięciami przeciwpożarowym 
Annex 1 to the Regulation of the Minister of Infrastructure of 11 August 2004 on the methods of declaring the conformity of construction products and the method of marking them with a construction mark (Polish Journal of Laws: Dz. U. $2004 \mathrm{nr} 198$ poz. 2041 as amended) /

Załącznik nr 1 do rozporządzenia Ministra Infrastruktury $z$ dnia 11 sierpnia 2004 r. w sprawie sposobów deklarowania zgodności wyrobów budowlanych oraz sposobu znakowania ich znakiem budowlanym (Dz.U. 2004 nr 198 poz. 2041 z późn.zm.)
Annex 1 to the Regulation of the Minister of Infrastructure and Construction of 17 November 2016 on the method of declaring the performance of construction products and the method of marking them with a construction mark (Polish Journal of Laws: Dz. U. 2016 poz. 1966) /

Załącznik nr 1 do rozporządzenia Ministra Infrastruktury i Budownictwa z dnia 17 listopada 2016 r. w sprawie sposobu deklarowania właściwości użytkowych wyrobów budowlanych oraz sposobu znakowania ich znakiem budowlanym (Dz. U. 2016 poz. 1966)
Smoke and heat control systems - components: smoke curtains, fire dampers, wires, mechanical fans, smoke dampers, control panels for fire brigades, manual smoke exhaust switches, power sources /

Instalacje kontroli rozprzestrzeniania dymu i ciepła - elementy składowe: kurtyny dymowe, klapy przeciwpożarowe, przewody, wentylatory mechaniczne, klapy dymowe, panele obsługi dla straży pożarnej, ręczne przyciski oddymiania, źródła zasilania
Smoke and heat control systems - components: smoke curtains, fire dampers, wires, mechanical fans, smoke dampers, relief dampers, control command devices, control panels for fire brigades, manual smoke exhaust switches, power sources, linear actuators, rotary actuators,

dampers for the inflow of compensating air, pressure detectors /

Systemy kontroli rozprzestrzeniania dymu i ciepła - elementy składowe: kurtyny dymowe, klapy przeciwpożarowe, przewody, wentylatory mechaniczne klapy dymowe, klapy odciążające, sterownicze urządzenia sterujące, panele obsługi dla straży pożarnej, ręczne przyciski oddymiania, źródła zasilania siłowniki liniowe, siłowniki obrotowe, przepustnice do napływu powietrza kompensacyjnego, czujniki ciśnienia
Evacuation systems - kits:

emergency evacuation lighting systems, systems for managing the opening of exits on escape routes, evacuation kits / Systemy ewakuacyjne - zestawy:

systemy awaryjnego oświetlenia ewakuacyjnego, systemy zarządzania otwarciem wyjść na drogach ewakuacyjnych, zestawy do ewakuacji

Evacuation systems - components:

control and signaling devices, power sources, actuators, controlled interfaces,

luminaires for emergency lighting, control panels for fire brigades, rescue sleeves /

Systemy ewakuacyjne - elementy składowe:

urządzenia sterujące i sygnalizujące, źródła zasilania, urządzenia wykonawcze, interfejsy przejść kontrolowanych, oprawy oświetleniowe do oświetlenia awaryjnego, panele obsługi dla straży pożarnej, rękawy ratownicze 
Annex to the Regulation of the Minister of Investment and Development of 13 June 2018 amending the Regulation on the method of declaring the performance of construction products and the method of marking them with a construction mark (Polish Journal of Laws: Dz. U. 2018 poz. 1233) / Załącznik do rozporządzenia Ministra Inwestycji i Rozwoju z dnia 13 czerwca 2018 r. zmieniającego rozporządzenie w sprawie sposobu deklarowania właściwości użytkowych wyrobów budowlanych oraz sposobu znakowania ich znakiem budowlanym (Dz.U. 2018 poz. 1233)
Regulation of the Minister of Development, Labor and Technology of 4 December 2020 amending the Regulation on the method of declaring the performance of construction products and the method of marking them with a construction mark (Polish Journal of Laws: Dz. U. 2020 poz. 2297) /

Rozporządzenie Ministra Rozwoju, Pracy i Technologii z dnia

4 grudnia 2020 r. zmieniające rozporządzenie w sprawie sposobu deklarowania właściwości użytkowych wyrobów budowlanych oraz sposobu znakowania ich znakiem budowlanym
Smoke and heat control systems - components: smoke curtains, fire dampers, wires, mechanical fans, smoke dampers, relief dampers, control and signaling devices, control panels for fire brigades, manual smoke exhaust switches, power sources, linear actuators, rotary actuators, dampers for the inflow of compensating air, pressure detectors /

Systemy kontroli rozprzestrzeniania dymu i ciepła - elementy składowe: kurtyny dymowe, klapy przeciwpożarowe, przewody, wentylatory mechaniczne, klapy dymowe, klapy odciążające (upustowe), urządzenia sterujące i sygnalizujące, panele obsługi dla straży pożarnej, ręczne przyciski oddymiania, źródła zasilania, siłowniki liniowe, siłowniki obrotowe, przepustnice do napływu powietrza kompensacyjnego, czujniki ciśnienia

\section{Smoke and heat control systems - components:}

smoke curtains, fire dampers, wires, devices for mechanical smoke and heat extraction (fans), smoke dampers, relief dampers, control and signaling devices, control panels for fire brigades, manual smoke exhaust switches, power sources, linear actuators, rotary actuators, dampers for the inflow of compensating air, pressure detectors /

Systemy kontroli rozprzestrzeniania dymu i ciepła - elementy składowe: kurtyny dymowe, klapy przeciwpożarowe, przewody, urządzenia do mechanicznego odprowadzania dymu i ciepła (wentylatory), klapy dymowe, klapy odciążające (upustowe), urządzenia sterujące i sygnalizujące, panele obsługi dla straży pożarnej, ręczne przyciski oddymiania, źródła zasilania, siłowniki liniowe, siłowniki obrotowe, przepustnice do napływu powietrza kompensacyjnego, czujniki ciśnienia
Evacuation systems - kits:

emergency evacuation lighting systems, systems for managing the opening of exits on escape routes, evacuation kits / Systemy ewakuacyjne - zestawy:

systemy awaryjnego oświetlenia ewakuacyjnego, systemy zarządzania otwarciem wyjść na drogach ewakuacyjnych, zestawy do ewakuacji
Evacuation systems - kits:

emergency evacuation lighting systems, systems for managing the opening of exits on escape routes, evacuation kits /

Systemy ewakuacyjne - zestawy:

systemy awaryjnego oświetlenia ewakuacyjnego, systemy zarządzania otwarciem wyjść na drogach ewakuacyjnych, zestawy do ewakuacji
Evacuation systems - components:

control and signaling devices, power sources, actuators, controlled interfaces, luminaires for dynamic emergency lighting, control panels for fire brigades, rescue sleeves /

Systemy ewakuacyjne - elementy składowe:

urządzenia sterujące i sygnalizujące, źródła zasilania, urządzenia wykonawcze, interfejsy przejść kontrolowanych, oprawy oświetleniowe do dynamicznego oświetlenia ewakuacyjnego, panele obsługi dla straży pożarnej, rękawy ratownicze

\section{Evacuation systems - components:}

control and signaling devices, power sources, actuators, controlled interfaces, luminaires for dynamic emergency lighting, control panels for fire brigades, rescue sleeves /

Systemy ewakuacyjne - elementy składowe:

urządzenia sterujące i sygnalizujące, źródła zasilania, urządzenia wykonawcze, interfejsy przejść kontrolowanych, oprawy oświetleniowe do dynamicznego oświetlenia ewakuacyjnego, panele obsługi dla straży pożarnej, rękawy ratownicze
Systems integrating fire protection devices - kits: visualization and/or control systems /

Systemy integrujące urządzenia przeciwpożarowe - zestawy: systemy do wizualizacji i/lub sterowania
Systems integrating fire protection devices - kits:

visualization and control systems /

Systemy integrujące urządzenia przeciwpożarowe - zestawy:

systemy do wizualizacji i sterowania
Fire protection power switches - kits

Przeciwpożarowe wyłączniki prądu - zestawy
Fire protection power switches - kits /

Przeciwpożarowe wyłączniki prądu - zestawy
Fire protection power switches - components:

actuators, signaling devices, urządzenia wykonawcze /

Przeciwpożarowe wyłączniki prądu - elementy składowe: urządzenia uruchamiające, urządzenia sygnalizujące, urządzenia wykonawcze
Fire protection power switches - components

actuators, signaling devices, urządzenia wykonawcze /

Przeciwpożarowe wyłączniki prądu - elementy składowe: urządzenia uruchamiające, urządzenia sygnalizujące, urządzenia wykonawcze

Comments:

Purple, red, orange mark the changes introduced in Annex 1 to the regulations listed in columns I and II, III

Orange, green, blue and navy blue mark the changes introduced in Annex 1 to the regulations listed in columns II III and IV /

Uwagi:

Kolorem fioletowym, czerwonym, pomarańczowym oznaczono zmiany wprowadzone w załączniku nr 1 w rozporządzeniach podanych w kolumnach I i II, III Kolorem pomarańczowym, zielonym, niebieskim i granatowym oznaczono zmiany wprowadzone w załączniku nr 1 w rozporządzeniach podanych w kolumnach II III i IV

Source: Own elaboration based on the regulation [1-4].

Źródło: Opracowanie własne na podstawie rozporządzenia [1-4] 


\section{Marking and accompanying documents during placing construction products on the market or making them available on the national market}

None of the amending acts introduced changes regarding the marking of a construction product with a construction mark, the information that must accompany the marking has not changed either. These requirements are presented in $\S 10,12$ and 13 of the Regulation of the Minister of Infrastructure and Construction of 17 November 2016 [1].

There were also no changes to the formula and content of the national declaration of performance - they are in line with Annex 1 to the above regulation [1]. The method of making the national declaration available has also remained unchanged and complies with $\S 9$ of this regulation.

\section{Transitional period}

The Regulation of the Minister of Infrastructure and Construction of 17 November 2016 on the method of declaring the performance of construction products and the method of marking them with a construction mark indicated two transition periods for the preparation of national declarations of performance. The first one referred to the national declarations issued for products for which there was no obligation to issue a declaration before, while the second one provided information related to the procedure in case of declarations that were prepared before 31 December 2018 . The above document specifies construction products for which, before 31 December 2018, there was no obligation to mark them with a construction mark (marked in red in Table 1), as a result of which a national declaration of performance was not prepared for them when placing on the market or making them available on the national market until 30 June 2018. The Regulation of the Minister of Investment and Development of June 13, 2018 [2] extended the transition period until 30 June 2019.

It is worth noting that the Regulation of the Minister of Development, Labor and Technology of 4 December 2020 [4] indicates that for pump sets for fire-fighting water systems, the manufacturer of the construction product is not obliged to draw up a national declaration of performance when placing on the market or making available on the national market of such a construction product until 31 December 2021.

Manufacturers of construction products who prepared a national declaration of performance and marked them with a construction mark before 31 December 2016 (pursuant to Article 5 (2) of the Act of 25 June 2015 amending the Act on construction products, the Construction Law Act and of the Act on amending the Act on construction products and the Act on the conformity assessment system Polish Journal of Laws: Dz. U. 2015 poz. 1165), could use the method of marking a construction product with a construction mark and the scope of information accompanying this product as specified in that Regulations until 30 June 2017. In this case, no amending act extended this transitional period.

\section{Znakowanie oraz dokumenty towarzyszące podczas wprowadzania do obrotu lub udostępniania na rynku krajowym wyrobów budowlanych}

Żaden z aktów zmieniających nie wprowadził zmian dotyczących znakowania wyrobu budowlanego znakiem budowlanym, informacje jakie muszą towarzyszyć znakowaniu także nie uległy zmianie. Niniejsze wymagania przedstawiono w $\S 10$, 12 i 13 rozporządzenia Ministra Infrastruktury i Budownictwa z dnia 17 listopada 2016 r. [1].

Nie wprowadzono zmian także we wzorze i treści krajowej deklaracji właściwości użytkowych - są one zgodne z załącznikiem 1 do powyższego rozporządzenia [1]. Sposób udostępniania krajowej deklaracji również pozostał bez zmian i jest zgodny z $\S 9$ tego rozporządzenia.

\section{Okres przejściowy}

Rozporządzenie Ministra Infrastruktury i Budownictwa z dnia 17 listopada 2016 r. w sprawie sposobu deklarowania właściwości użytkowych wyrobów budowlanych oraz sposobu znakowania ich znakiem budowlanym wskazało dwa okresy przejściowe dotyczące sporządzania krajowych deklaracji właściwości użytkowych. Pierwszy z nich odnosił się do krajowych deklaracji wystawianych dla wyrobów, dla których wcześniej nie istniał obowiązek wystawiania deklaracji, natomiast drugi zawierał informację związaną z postępowaniem w przypadku deklaracji, jakie sporządzono przed 31 grudnia 2018 r. Powyższy dokument określa wyroby budowlane, dla których przed 31 grudnia 2018 r. nie istniał obowiązek znakowania znakiem budowlanym, (wyróżnione kolorem czerwonym w tabeli 1), w konsekwencji czego nie sporządzano dla nich krajowej deklaracji właściwości użytkowych przy wprowadzaniu do obrotu lub udostępnianiu na rynku krajowym do dnia 30 czerwca 2018 r. Rozporządzenie Ministra Inwestycji i Rozwoju z dnia 13 czerwca 2018 r. [2] wydłużyło okres przejściowy do 30 czerwca $2019 \mathrm{r}$.

Na uwagę zasługuje fakt, iż rozporządzenie Ministra Rozwoju, Pracy i Technologii z dnia 4 grudnia 2020 r. [4] wskazuje, że dla zespołów pomp do instalacji wodociągowych przeciwpożarowych producent wyrobu budowlanego nie jest zobowiązany sporządzać krajowej deklaracji właściwości użytkowych przy wprowadzaniu do obrotu lub udostępnianiu na rynku krajowym takiego wyrobu budowlanego do 31 grudnia $2021 \mathrm{r}$.

Producenci wyrobów budowlanych, którzy sporządzili krajową deklarację właściwości użytkowych oraz znakowali je znakiem budowlanym przed 31 grudniem 2016 r. (na podstawie art. 5 ust. 2 ustawy z dnia 25 czerwca 2015 r. o zmianie ustawy o wyrobach budowlanych, ustawy - Prawo budowlane oraz ustawy o zmianie ustawy o wyrobach budowlanych oraz ustawy o systemie oceny zgodności Dz. U. 2015 poz. 1165), mogli stosować określony w tymże rozporządzeniu sposób znakowania wyrobu budowlanego znakiem budowlanym oraz zakres informacji towarzyszących temu wyrobowi do dnia 30 czerwca 2017 r. W tym przypadku żaden akt zmieniający nie wydłużył tego okresu przejściowego. 
Therefore, from 31 December 2020, for all construction products covered by the Regulation of the Minister of Infrastructure and Construction of 17 November 2016 on the method of declaring the performance of construction products and the method of marking them with a construction mark (Polish Journal of Laws: Dz. U. z 2016 r. poz. 1966; zm.: Dz. U. z 2018 r. poz. 1233, z 2019 r. poz. 1176 i poz. 2164 oraz z 2020 r. poz. 2297) - except for pump sets for fire-fighting water systems, for which the transitional period has been extended until 31 December 2021 - the manufacturer is required to mark the product in accordance with $\S 11$ of the Regulation [1] and prepare a national declaration of performance in accordance with Annex 2 to this Regulation.

\section{Conclusion}

This article presents the scope of changes that were introduced in other legal acts prior to the Regulation of the Minister of Infrastructure and Construction of 17 November 2016 [1]. The introduced changes were discussed and their impact on the national assessment and verification of the constancy of performance of construction products was analyzed. In addition, the current list of construction products for fire protection has been presented, for which the manufacturer is obliged to issue a national declaration of performance and mark them with a construction mark.
W związku z powyższym od 31 grudnia 2020 r. dla wszystkich wyrobów budowlanych objętych rozporządzeniem Ministra Infrastruktury i Budownictwa z dnia 17 listopada 2016 r. w sprawie sposobu deklarowania właściwości użytkowych wyrobów budowlanych oraz sposobu znakowania ich znakiem budowlanym (Dz. U. z 2016 r. poz. 1966; zm.: Dz. U. z 2018 r. poz. 1233, z 2019 r. poz. 1176 i poz. 2164 oraz z 2020 r. poz. 2297) - poza zespołami pomp do instalacji wodociągowych przeciwpożarowych, dla których okres przejściowy został przedłużony do 31 grudnia $2021 \mathrm{r}$. - producent ma obowiązek znakować wyrób zgodnie z $§ 11$ rozporządzenia [1] oraz sporządzać krajową deklarację właściwości użytkowych zgodną z załącznikiem 2 do tego rozporządzenia.

\section{Podsumowanie}

Niniejszy artykuł przedstawia zakres zmian, które zostały wprowadzone w innych aktach prawnych przed rozporządzeniem Ministra Infrastruktury i Budownictwa $z$ dnia 17 listopada 2016 r. [1]. Omówiono wprowadzone zmiany oraz przeanalizowano ich wpływ na prowadzenie krajowej oceny i weryfikacji stałości właściwości użytkowych wyrobów budowlanych. Ponadto przedstawiono aktualną listę wyrobów budowanych służących ochronie przeciwpożarowej, dla których producent zobowiązany jest wystawić krajową deklarację właściwości użytkowych oraz znakować je znakiem budowlanym.

\section{Literature / Literatura}

[1] Rozporządzenie Ministra Infrastruktury i Budownictwa z dnia 17 listopada 2016 r. w sprawie sposobu deklarowania właściwości użytkowych wyrobów budowlanych oraz sposobu znakowania ich znakiem budowlanym (Dz. U. 2016 r. poz. 1966).

[2] Rozporządzenie Ministra Inwestycji i Rozwoju z dnia 13 czerwca 2018 r. zmieniające rozporządzenie w sprawie sposobu deklarowania właściwości użytkowych wyrobów budowlanych oraz sposobu znakowania ich znakiem budowlanym (Dz. U. 2018 r. poz. 1233).

[3] Rozporządzenie Ministra Infrastruktury z dnia 11 sierpnia 2004 r. w sprawie sposobów deklarowania zgodności wyrobów budowlanych oraz sposobu znakowania ich znakiem budowlanym (Dz. U. 2004 r. Nr 198 poz. 2041 z późn.zm.).
[4] Rozporządzenie Ministra Rozwoju, Pracy i Technologii z dnia 4 grudnia $2020 \mathrm{r}$. zmieniające rozporządzenie $\mathrm{w}$ sprawie sposobu deklarowania właściwości użytkowych wyrobów budowlanych oraz sposobu znakowania ich znakiem budowlanym (Dz. U. 2020 poz. 2297).

[5] Ustawa z dnia 16 kwietnia 2004 r. o wyrobach budowlanych (Dz. U. 2004 r. Nr 92, poz. 881 z późn.zm.).

[6] Ustawa z dnia 30 sierpnia 2002 r. o systemie oceny zgodności (tj. Dz. U. 2010 r. Nr 138, poz. 935 z późn. zm.).

[7] Rozporządzenie Ministra Infrastruktury i Budownictwa $z$ dnia 17 listopada 2016 r. w sprawie krajowych ocen technicznych (Dz. U. 2016 r. poz. 1968).

[8] Iwańska M., Jankowska K., Kowalczyk A., Zmiany w zakresie wymagań wprowadzania do obrotu lub udostępniania na rynku krajowym wyrobów budowlanych służących ochronie 
przeciwpożarowej znakowanych znakiem budowlanym, BITP Vol. 52 Issue 4, 2018, pp. 168-183, https://www.doi. org/10.12845/bitp.52.4.2018.10.

[9] Rozporządzenie Ministra Inwestycji i Rozwoju z dnia 19 czerwca 2019 r. zmieniające rozporządzenie w sprawie sposobu deklarowania właściwości użytkowych wyrobów budowlanych oraz sposobu znakowania ich znakiem budowlanym (Dz. U. poz. 1176).
[10] Rozporządzenie Ministra Finansów, Inwestycji i Rozwoju z dnia 21 października 2019 r. (Dz. U. poz. 2164) zmieniające rozporządzenie w sprawie sposobu deklarowania właściwości użytkowych wyrobów budowlanych oraz sposobu znakowania ich znakiem budowlanym.
KATARZYNA JANKOWSKA, M.SC. ENG. - a graduate of full-time 1st and 2nd degree studies at the Faculty of Fire Safety Engineering at the Main School of Fire Service. Since 2016, an employee of CNBOP-PIB Certification Department in the area of fire suppression and extinguishing systems, smoke and heat control systems as well as cables and wires for general use.

AGNIESZKA KOWALCZYK, M.SC. - a graduate of the Lazarski University in Warsaw at the Faculty of Law and Administration, with a major in administration. For over 23 years she has been working at CNBOP-PIB, and for 15 years - in the Certification Department as a specialist in quality management systems. She is also a management systems auditor with many years of experience both in Poland and abroad.

MARTA IWAŃSKA, M.SC. - a graduate of Collegium Civitas in Warsaw at the Faculty of Sociology, with a major in management of non-governmental organizations. For over eight years she has been working in CNBOP-PIB Certification Department as a specialist in quality management systems. She is a co-author of a number of publications related to fire protection.
MGR INŻ.. KATARZYNA JANKOWSKA - absolwentka dziennych studiów I ill stopnia na Wydziale Inżynierii Bezpieczeństwa Pożarowego Szkoły Głównej Służby Pożarniczej. Od 2016 roku pracownik Jednostki Certyfikującej CNBOP-PIB w obszarze systemów tłumienia i gaszenia pożaru, systemów kontroli rozprzestrzeniania dymu i ciepła oraz kabli i przewodów zastosowania ogólnego.

MGR AGNIESZKA KOWALCZYK - absolwentka Uczelni Łazarskiego w Warszawie na wydziale prawa i administracji, kierunek administracja. Od ponad 23 lat pracuje w CNBOP-PIB, a od 15 lat pracuje w Jednostce Certyfikującej jako specjalista ds. zarządzania systemami jakości. Jest również auditorem systemów zarządzania z wieloletnim doświadczeniem zarówno w Polsce, jak i zagranicą.

MGR MARTA IWAŃSKA - absolwentka Collegium Civitas w Warszawie na wydziale socjologii, kierunek zarządzanie organizacjami pozarządowymi. Od ponad ośmiu lat pracuje w Jednostce Certyfikującej w CNBOP-PIB jako specjalista ds. systemów zarządzania jakością. Jest współautorką szeregu publikacji związanych z ochroną przeciwpożarową. 